\title{
IN ELECTIVE CORONARY ARTERY BYPASS GRAFTING, PREOPERATIVE TROPONIN T LEVEL PREDICTS THE RISK OF MYOCARDIAL INFARCTION
}

Michel Carrier, MD

L. Conrad Pelletier, MD

Raymond Martineau, MD

Michel Pellerin, MD

B. Charles Solymoss, MD
Objective: Several combinations of risk factors for death or cardiac events after coronary artery bypass grafting have been described. We studied the prognostic value of the preoperative serum levels of cardiac troponin $T$. Methods: We studied 468 patients who underwent elective coronary artery bypass grafting. Preoperative and postoperative levels of cardiac troponin $\mathrm{T}$ and creatine kinase MB, electrocardiograms, clinical data, and events were recorded prospectively. No acute ischemic changes were present on the electrocardiogram before the operations, and preoperative creatine kinase MB serum levels were within normal limits in all patients. Results: Ninety-seven $(97 / 468,21 \%)$ patients had serum levels of troponin T greater than $0.02 \mu \mathrm{g} / \mathrm{L}$ within 24 hours before coronary artery bypass grafting. Hospital mortality was similar in this group and in the patients with preoperative levels less than $0.02 \mu \mathrm{g} / \mathrm{L}$ (1\% in each group). Nine patients $(9 / 97,9 \%)$ with elevated levels of troponin $\mathbf{T}$ before the operation had a perioperative myocardial infarction compared with 12 patients $(12 / 371,3 \%)$ among the group with lower troponin $T$ levels $(p=0.015, R R=2.9)$. Congestive heart failure occurred in $10(10 / 97,10 \%)$ and $8(8 / 371,2 \%)$ patients, respectively $(p=0.0009, R R=4.8)$. Intensive care unit $(p=$ $0.002)$ and postoperative hospital length of stay $(p=0.09)$ were all longer in patients with the elevated preoperative troponin $T$ level. In a logistic regression analysis, troponin $T$ level before the operation was the variable most strongly correlated with postoperative myocardial infarction $(p=$ 0.003). Conclusion: Preoperative troponin $T$ stratification before coronary artery bypass grafting identifies a subgroup of patients with increased risk of postoperative cardiac complications. (J Thorac Cardiovasc Surg 1998; 115:1328-34)
$S$ everal models assessing cardiac events and mortality after coronary artery bypass grafting (CABG) were developed to predict outcome after surgery and to measure variations in the quality of care. ${ }^{1-3}$ Although these models give consistent predictions, statistical computation remains difficult at the patient's bedside. In addition, patients are now referred for coronary surgery at a far more advanced stage of the disease and thus

From the Departments of Surgery, Anesthesia, and Laboratory Medicine, Montreal Heart Institute, Montreal, Quebec, Canada.

Received for publication Nov. 5, 1997; revisions requested Dec. 19, 1997; revisions received Jan. 22, 1998; accepted for publication Jan. 23, 1998.

Address for reprints: Michel Carrier, MD, Montreal Heart Institute, 500 Bélanger St. East, Montreal, Quebec, Canada.

Copyright (c) 1998 by Mosby, Inc.

$0022-5223 / 98 \$ 5.00+0 \quad \mathbf{1 2 / 1 / 8 9 1 4 6}$ present a greater risk. ${ }^{4}$ Therefore it remains difficult to predict cardiac events after CABG operations based on preoperative clinical and angiographic criteria.

Cardiac-specific troponin proteins are highly sensitive markers of myocardial necrosis. ${ }^{5}$ The subunit troponin $\mathrm{T}$ is specific for myocardial tissue. It is not present in the serum of healthy volunteers and has been successfully used for risk stratification in acute myocardial ischemia. ${ }^{6}$ In the present study, the relative risk of cardiac events after elective CABG has been assessed with the use of the preoperative troponin T serum levels, assuming that patients with detectable troponin $\mathrm{T}$ levels before the operation were at higher risk of cardiac events after the operation. The presence of circulating troponin $\mathrm{T}$ in patients undergoing elective $\mathrm{CABG}$ is probably the result of unrecognized ongoing damage to the myocardium. 


\section{Patients and methods}

From 1992 to 1995, 468 patients who underwent elective CABG at the Montreal Heart Institute were prospectively studied to evaluate myocardial protection with intermittent warm versus cold blood cardioplegia ${ }^{7}$ or with antegrade versus retrograde administration of blood cardioplegia. ${ }^{8}$ All patients gave informed consent, and the study protocols were approved by the Institutional Review Board of the Montreal Heart Institute.

Patients with any of the following criteria were excluded: (1) operation within 7 days of an acute myocardial infarction (MI); (2) emergency operation for acute coronary occlusion at angioplasty; (3) emergency surgical procedures performed outside of normal working hours; (4) $\mathrm{CABG}$ operations associated with any other cardiac surgical procedure; (5) age older than 75 years; and (6) preoperative renal dysfunction (creatinine serum level $>$ $200 \mathrm{mmol} / \mathrm{L}$ ).

Surgical technique and myocardial protection. Operations were performed with the use of internal thoracic artery and saphenous vein grafts in all patients. The cardioplegic solution was infused through a $14 \mathrm{~F}$ doublelumen needle (Medtronic Inc., Grand Rapids, Mich.) in the ascending aorta or through a self-inflating balloon retrograde catheter through the coronary sinus (14F selfinflating balloon; Research Medical Inc., Midvale, Utah). The cardioplegia infusion set (CardioMed Supplies Inc., Gormley, Ontario, Canada) consisted of two inflow lines for mixing of the crystalloid solution with blood from the arterial circuit at a ratio of $4: 1$.

After the ascending aorta was crossclamped, cardioplegic arrest was achieved in all patients by antegrade coronary infusion of $300 \mathrm{ml}$ of high-potassium solution over a period of 3 to 5 minutes, at a perfusion pressure not exceeding $250 \mathrm{~mm} \mathrm{Hg}$ in the infusion line, and at the same temperature as the cardiopulmonary bypass (CPB) perfusate $\left(33^{\circ} \mathrm{C}\right.$, warm cardioplegia). Diastolic arrest was usually obtained before termination of the initial infusion. Thereafter and for the remainder of the procedure, intermittent bolus infusions of 200 to $300 \mathrm{ml}$ of lowpotassium solution were administered antegradely in the ascending aorta or retrogradely through the coronary sinus after each distal anastomosis.

Markers of myocardial ischemia and diagnosis of perioperative MI. Blood samples for determination of the serum levels of total creatine kinase (CK), catalytic activity of its MB isoenzyme (CK-MB), and troponin T levels were taken before the beginning of the operation and 1 hour, 3, 6, 12, 24, and 48 hours after chest closure. Electrocardiographic tracings were obtained the day before the operation, on arrival in the intensive care unit, and on postoperative days 1,2 , and 3 . The diagnosis of perioperative MI was based on the presence of two of the following criteria: (1) new $\mathrm{Q}$ wave or disappearance of $\mathrm{R}$ wave on the postoperative electrocardiographic tracing; (2) serum CK-MB activity concentration higher than 100 IU/L 12 to 24 hours after the operation; and (3) a positive myocardial pyrophosphate scan. ${ }^{9}$ The latter was performed only in the presence of an abnormal CK-MB increase without changes on the electrocardiographic tracings.
Table I. Preoperative clinical, angiographic and laboratory characteristics of 468 patients according to preoperative troponin $T$ serum levels

\begin{tabular}{|c|c|c|c|}
\hline \multirow[b]{2}{*}{ Variables } & \multicolumn{2}{|c|}{ Troponin $T$} & \multirow[b]{2}{*}{$\begin{array}{c}p \\
\text { Value }\end{array}$} \\
\hline & $\begin{array}{c}>0.02 \mu g / L \\
(n=97)\end{array}$ & $\begin{array}{l}\leq 0.02 \mu g / L \\
(n=371)\end{array}$ & \\
\hline Age (yr) & $64 \pm 9$ & $61 \pm 10$ & 0.004 \\
\hline \multicolumn{4}{|l|}{ Sex } \\
\hline Men & $77(78 \%)$ & $311(84 \%)$ & 0.3 \\
\hline Women & $20(22 \%)$ & $60(16 \%)$ & \\
\hline \multicolumn{4}{|l|}{ Angina } \\
\hline Unstable & $54(57 \%)$ & $148(40 \%)$ & 0.006 \\
\hline Stable & $43(43 \%)$ & $223(60 \%)$ & \\
\hline Classes III+IV & $78(79 \%)$ & $264(71 \%)$ & 0.009 \\
\hline Classes I+II & $19(21 \%)$ & $107(29 \%)$ & \\
\hline Previous MI & $69(71 \%)$ & $219(59 \%)$ & 0.02 \\
\hline History of CHF & $17(18 \%)$ & $16(4 \%)$ & 0.00004 \\
\hline Left main stenosis & $21(22 \%)$ & $78(21 \%)$ & 0.8 \\
\hline One-vessel disease & 1 & 1 & \\
\hline Two-vessel disease & 25 & 101 & 0.6 \\
\hline Three-vessel disease & 71 & 269 & \\
\hline LV ejection fraction (\%) & $47 \pm 14$ & $57 \pm 12$ & 0.000001 \\
\hline Repeat CABG $(n)$ & $17(18 \%)$ & $49(13 \%)$ & 0.3 \\
\hline $\begin{array}{l}\text { Total CK }(\mathrm{IU} / \mathrm{L}) \\
\quad(\text { mean } \pm \mathrm{SD})\end{array}$ & $71 \pm 49$ & $63 \pm 51$ & 0.2 \\
\hline $\begin{array}{l}\text { CK-MB (IU/L) } \\
\quad(\text { mean } \pm \text { SD })\end{array}$ & $9 \pm 10$ & $7 \pm 7$ & 0.1 \\
\hline $\begin{array}{l}\text { Troponin } \mathrm{T}(\mu \mathrm{g} / \mathrm{L}) \\
\quad(\text { mean } \pm \mathrm{SD})\end{array}$ & $0.33 \pm 0.91$ & $0.005 \pm 0.007$ & 0.00001 \\
\hline
\end{tabular}

$M I$, Myocardial infarction; $C H F$, congestive heart failure; $L V$, left ventricle; $C A B G$, coronary artery bypass grafting; $C K$, creatine kinase.

The serum CK level (normal range 24 to 195 IU/L) and, after inhibition of the monomer with monoclonal antibody, the CK-MB catalytic activity (normal range 0 to 30 IU/L) were measured by standard methods by means of a Hitachi 717 analyzer and reagents from BoehringerMannheim (Mannheim, Germany). The serum cardiac troponin $\mathrm{T}$ concentration (normal range 0 to $0.02 \mu \mathrm{g} / \mathrm{L}$ ) was analyzed by an enzyme immunoassay using reagents and an ES300 analyzer from Boehringer-Mannheim. In the present study, $0.02 \mu \mathrm{g} / \mathrm{L}$ was chosen as the upper value of the normal range, although some investigators have determined the limit to be $0.015 \mu \mathrm{g} / \mathrm{L} .{ }^{10}$ Thus patients with detectable circulating troponin $\mathrm{T}$ at a level greater than $0.02 \mu \mathrm{g} / \mathrm{L}$ before the operation were compared with those who had preoperative circulating levels of $0.02 \mu \mathrm{g} / \mathrm{L}$ or less. In a study of 32 patients with chronic stable angina treated medically with no intention to offer CABG in our institution, troponin $\mathrm{T}$ serum levels averaged $0.012 \pm$ $0.013 \mu \mathrm{g} / \mathrm{L}$.

The clinical diagnosis of congestive heart failure after CABG was based on radiologic evidence or signs of pulmonary venous congestion after stabilization of body weight immediately after the operation and the use of angiotensin-converting enzyme inhibitors to control the patients' clinical signs and symptoms.

Statistical analysis. Data were analyzed by Student's $t$ test for continuous variables and by the $\chi^{2}$ test for 
Table II. Operative data of 468 patients undergoing $C A B G$ according to preoperative troponin $T$ serum levels

\begin{tabular}{|c|c|c|c|}
\hline \multirow[b]{2}{*}{ Variables } & \multicolumn{2}{|c|}{ Troponin $T$} & \multirow[b]{2}{*}{$\begin{array}{c}p \\
\text { Value }\end{array}$} \\
\hline & $\begin{array}{c}>0.02 \mu g / L \\
(n=97)\end{array}$ & $\begin{array}{l}\leq 0.02 \mu g / L \\
(n=371)\end{array}$ & \\
\hline Grafts per patient, mean & $2.9 \pm 1$ & $2.9 \pm 1$ & 0.9 \\
\hline Complete revascularization & $86(89 \%)$ & $315(85 \%)$ & 0.4 \\
\hline CPB time (min) & $90 \pm 33$ & $81 \pm 26$ & 0.007 \\
\hline Crossclamp time (min) & $53 \pm 19$ & $49 \pm 17$ & 0.07 \\
\hline $\begin{array}{l}\text { Total volume of cardiople- } \\
\text { gia }(\mathrm{ml})\end{array}$ & $1092 \pm 398$ & $1025 \pm 432$ & 0.2 \\
\hline \multicolumn{4}{|l|}{ Cardioplegia } \\
\hline Warm & $48(49 \%)$ & $244(65 \%)$ & 0.004 \\
\hline Cold & $49(51 \%)$ & $126(35 \%)$ & \\
\hline Antegrade & $66(68 \%)$ & $260(70 \%)$ & 0.6 \\
\hline Retrograde & $31(32 \%)$ & $111(30 \%)$ & \\
\hline \multicolumn{4}{|l|}{ Blood losses (ml) } \\
\hline Intraoperative & $669 \pm 415$ & $593 \pm 339$ & 0.1 \\
\hline Postoperative & $859 \pm 684$ & $910 \pm 737$ & 0.6 \\
\hline $\begin{array}{l}\text { Weaning from bypass with } \\
\text { inotropic agents }\end{array}$ & $23(24 \%)$ & $67(18 \%)$ & 0.2 \\
\hline $\begin{array}{l}\text { Weaning from bypass with } \\
\text { vasopressors }\end{array}$ & $44(45 \%)$ & $104(28 \%)$ & 0.002 \\
\hline $\begin{array}{l}\text { Weaning from bypass with } \\
\text { IABP }\end{array}$ & $7(7 \%)$ & $4(1 \%)$ & 0.0005 \\
\hline \multicolumn{4}{|l|}{ Cardiac index $\left(\mathrm{L} / \mathrm{min} / \mathrm{m}^{2}\right)$} \\
\hline Before CPB & $2.23 \pm 0.47$ & $2.38 \pm 1.88$ & 0.4 \\
\hline After CPB & $2.8 \pm 0.68$ & $2.8 \pm 0.64$ & 0.7 \\
\hline $\begin{array}{l}\text { Spontaneous return to sinus } \\
\text { rhythm (No. of } \\
\text { patients) }\end{array}$ & $69(72 \%)$ & $278(75 \%)$ & 0.5 \\
\hline $\begin{array}{l}\text { Temporary cardiac pacing } \\
\text { (No. of patients) }\end{array}$ & $9(9 \%)$ & $26(7 \%)$ & 0.4 \\
\hline
\end{tabular}

$C P B$, Cardiopulmonary bypass; $I A B P$, intraaortic balloon pump.

discontinuous variables. The Mann-Whitney $U$ test and the Kruskal-Wallis one-way analysis of variance were used in the analyses of hospital stay. Logistic regression analyses of the following variables usually related to cardiac events after surgery were used to determine which variables correlated most strongly with MI and congestive heart failure during the perioperative period: (1) age at operation, (2) preoperative functional class, (3) previous MI (between 1 and 4 weeks of CABG), (4) number of coronary arteries diseased, (5) presence of left main coronary artery disease, (6) left ventricular ejection fraction, (7) previous CABG, and (8) stable/unstable angina. Analyses were performed with the use of the NCSS 6.0 program (Kaysville, Utah). Data are complete for all patients. Data are expressed as mean, standard deviation, and $95 \%$ confidence interval.

\section{Results}

Preoperative profile of patients. Among the 468 patients included in the present study, $97(21 \%)$ had a serum troponin $\mathrm{T}$ level above the limit of 0.02 $\mu \mathrm{g} / \mathrm{L}$ before elective $\mathrm{CABG}$ (group 1) and 371
Table III. Postoperative morbidity, mortality, and hospital length of stay of 468 patinets according to preoperative troponin $T$ serum levels

\begin{tabular}{|c|c|c|c|}
\hline \multirow[b]{2}{*}{ Variables } & \multicolumn{2}{|c|}{ Troponin $T$} & \multirow[b]{2}{*}{$\begin{array}{c}p \\
\text { Value }\end{array}$} \\
\hline & $\begin{array}{c}>0.02 \mu g / L \\
(n=97)\end{array}$ & $\begin{array}{l}\leq 0.02 \mu g / L \\
(n=371)\end{array}$ & \\
\hline Death, within 30 days & $1(1 \%)$ & $3(1 \%)$ & 0.9 \\
\hline Myocardial infarction & $9(9 \%)$ & $12(3 \%)$ & 0.015 \\
\hline Congestive heart failure & $10(10 \%)$ & $8(2 \%)$ & 0.0009 \\
\hline $\begin{array}{l}\text { Myocardial infarction or } \\
\text { congestive heart failure }\end{array}$ & $18(19 \%)$ & $16(4 \%)$ & 0.0001 \\
\hline Cerebrovascular accident & $1(1 \%)$ & $8(2 \%)$ & 0.7 \\
\hline $\begin{array}{c}\text { Reexploration for } \\
\text { hemorrhage }\end{array}$ & $1(1 \%)$ & $11(3 \%)$ & 0.5 \\
\hline \multicolumn{4}{|l|}{ Average length of stay (days) } \\
\hline $\begin{array}{l}\text { Intensive care unit } \\
\text { (median) }\end{array}$ & $6 \pm 9(4.6)$ & $4 \pm 3(4)$ & 0.0006 \\
\hline Hospital (median) & $10 \pm 10(7.5)$ & $8 \pm 4(7)$ & 0.09 \\
\hline
\end{tabular}

(79\%) patients had levels equal to or below 0.02 $\mu \mathrm{g} / \mathrm{L}$ (group 2).

Patients with a troponin $\mathrm{T}$ serum level greater than $0.02 \mu \mathrm{g} / \mathrm{L}$ before the operation (group 1) were older and more likely to have unstable or severe angina (class III-IV), congestive heart failure, or a lower left ventricular ejection fraction than patients with lower troponin $\mathrm{T}$ levels (group 2). Whereas the serum level of troponin $\mathrm{T}$ was higher in group 1, preoperative CK-MB serum levels were similar between the two groups (Table I).

Twenty-four patients of group 1 had an acute MI $15 \pm 2$ days before $\mathrm{CABG}$ and 25 patients of group 2 had an acute MI $20 \pm 2$ days before CABG ( $p=$ $0.02)$. No difference was detected in preoperative levels of troponin $\mathrm{T}$ between patients with and without recent acute MI. In group 2, serum levels averaged $0.005 \pm 0.006 \mu \mathrm{g} / \mathrm{L}(95 \%$ confidence interval [CI]: 0.004 to $0.006, n=347)$ in patients without recent acute MI and $0.008 \pm 0.007 \mu \mathrm{g} / \mathrm{L}$ (95\% CI: 0.004 to $0.010, n=24$ ) in patients with recent acute MI. In group 1 , these values were $0.180 \pm 0.278 \mu \mathrm{g} / \mathrm{L}$ (95\% CI: 0.115 to $0.244, n=74)$ and $0.802 \pm 1.744 \mu \mathrm{g} / \mathrm{L}$ (95\% CI: 0.048 to $1.556, n=$ 23), respectively. Preoperative troponin $\mathrm{T}$ serum levels averaged $0.022 \pm 0.07 \mu \mathrm{g} / \mathrm{L}$ (95\% CI: 0.012 to $0.030, n=266)$ in patients with stable angina and $0.138 \pm 0.648 \mu \mathrm{g} / \mathrm{L}(95 \% \mathrm{CI}: 0.049$ to $0.228, n=$ 202) in patients with unstable angina.

Operative data. Group 1 patients had a longer CPB time for a similar operation and needed more pharmacologic and mechanical support for weaning from CPB than patients who had normal circulating 


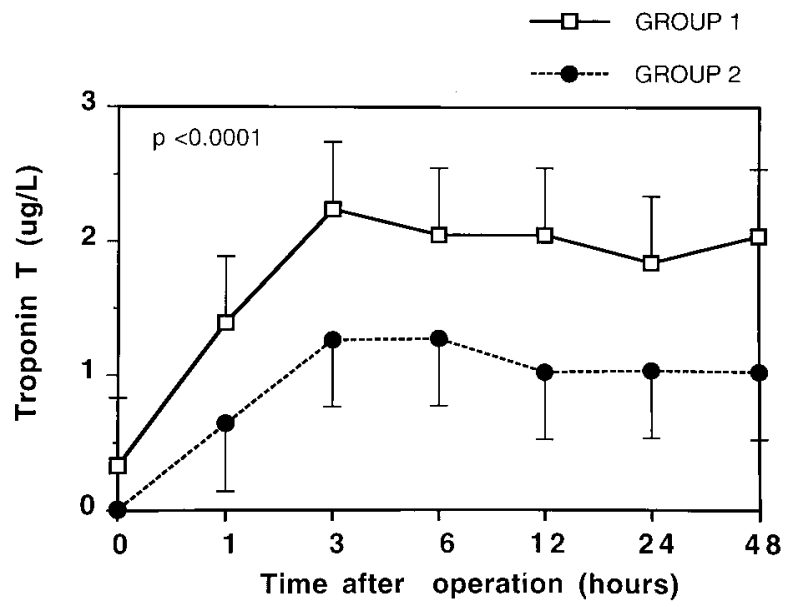

Fig. 1. Group 1 patients had higher serum levels of troponin T 1 to 48 hours after CABG than group 2 ( $p<$ $0.0001)$. Group 1 patients had serum levels of troponin $T$ greater than $0.02 \mu \mathrm{g} / \mathrm{L}$ and group 2 patients had serum levels of troponin $\mathrm{T}$ less than $0.02 \mu \mathrm{g} / \mathrm{L}$ in the preoperative period. Mean \pm standard error.

troponin $\mathrm{T}$ levels in the preoperative period (Table II). No significant difference was noted in the volume of cardioplegic solution infused nor in the route of administration of cardioplegic solution between the two groups, but group 2 patients had warm blood cardioplegia more often. Cardiac index, measured by the thermodilution method at the beginning and at the end of the operation, showed no difference between the two groups.

Postoperative morbidity and mortality. Although there was no difference in hospital mortality $(1 \%$ in each), patients with higher preoperative serum levels of troponin $\mathrm{T}$ were more likely to have a perioperative MI (9\% versus 3\%), congestive heart failure $(10 \%$ versus $2 \%)$, and acute MI or congestive heart failure (19\% versus $4 \%$ ) after CABG than patients with normal levels. In the present study, 12 patients had a new $Q$ wave with a significant increase in CK-MB concentration after CABG and nine patients had an increase in CK-MB release associated with a positive pyrophosphate scan, establishing the diagnosis of perioperative MI. $^{9}$ Lengths of stay in the intensive care unit and in the hospital were longer in patients with high preoperative troponin $\mathrm{T}$ levels (Table III).

Biochemical markers of myocardial damage and necrosis. Group 1 patients had higher levels of the cardiac-specific protein 1 to 48 hours after the operation than did group 2 patients, in whom levels of troponin $\mathrm{T}$ were within normal limits before the

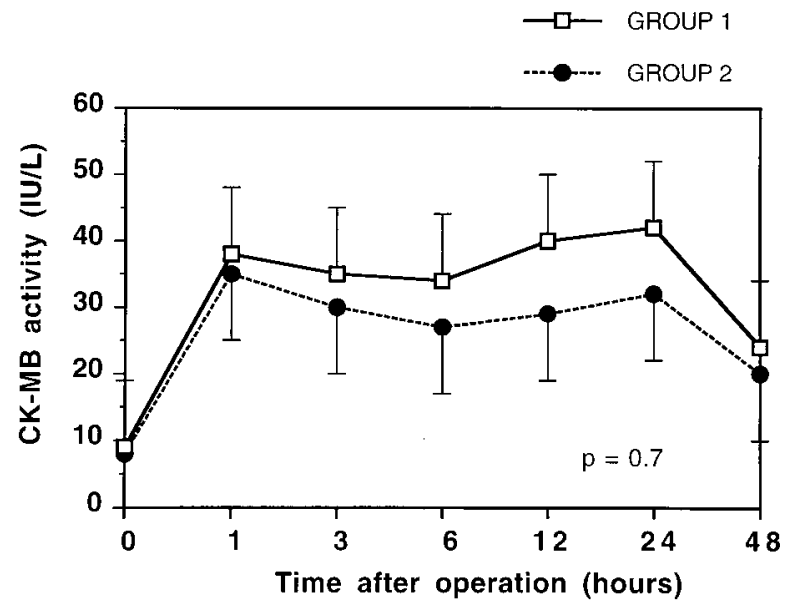

Fig. 2. Group 1 patients had higher serum levels of CK-MB 1 to 48 hours after CABG than group 2, but the difference was not statistically significant. Group 1 patients had serum levels of troponin $\mathrm{T}$ greater than 0.02 $\mu \mathrm{g} / \mathrm{L}$ and group 2 patients has serum levels of troponin $\mathrm{T}$ less than or equal to $0.02 \mu \mathrm{g} / \mathrm{L}$ in the preoperative period. Mean \pm standard error.

operation (Fig. 1, $p<0.0001$ ). Although CK-MB serum levels were higher after surgery in the former group, the difference was not statistically significant (Fig. 2, $p=0.7$ ).

The correlation between circulating troponin $\mathrm{T}$ levels in the preoperative period and the rate of MI after the operation shows a significant increase in cardiac events with increasing serum levels of the cardiac-specific protein (Fig. $3, p=0.03$ ). The logistic regression analysis showed that the factors most strongly correlated with perioperative MI were the higher level of circulating troponin $\mathrm{T}$ before surgery $\left(\chi^{2}=8.72, p=0.003\right)$ and reoperation for CABG $\left(\chi^{2}=4.36, p=0.037\right)$. The other independent variables were not significantly correlated with perioperative MI.

The variable most strongly associated with postoperative congestive heart failure and with any cardiac events defined as MI or congestive heart failure was the higher level of circulating troponin $\mathrm{T}$ before the operation $\left(\chi^{2}=5.83, p=0.016\right.$, and $\chi^{2}=$ $16.79, p=0.0001)$.

\section{Discussion}

Stratification of surgical risk. In the current era of quality control and of health care delivery reforms, prediction of clinical outcomes after cardiac surgical procedures has become a major issue for specialty societies, government, and third-party pay- 


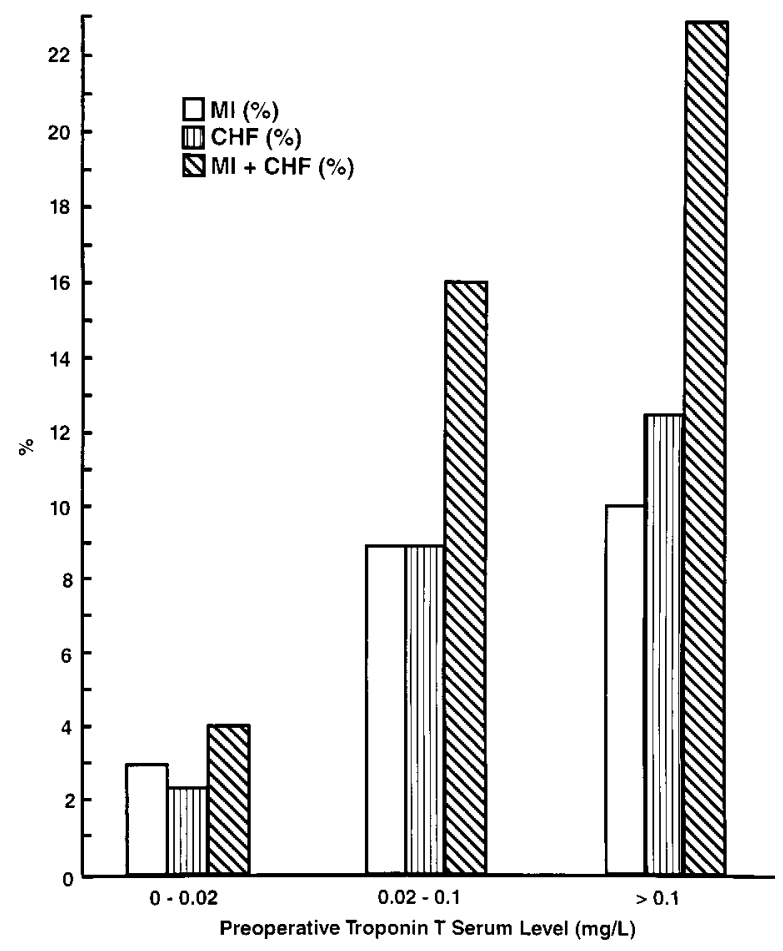

Fig. 3. The positive correlation between circulating troponin $\mathrm{T}$ levels before the operation and the rate of $\mathrm{MI}$ after the operation $(p=0.03)$, the rate of congestive heart failure $(C H F)(p=0.0006)$, and the rate of cardiac events $(M I+C H F)(p=0.0001)$ were significant. Group 2 comprised patients with troponin $\mathrm{T}$ levels below the discriminator value of $0.02 \mu \mathrm{g} / \mathrm{L}$. Group 1 comprised patients with elevated troponin $\mathrm{T}$ value. They were divided into two subgroups: troponin $\mathrm{T}$ value between 0.02 $\mu / \mathrm{L}$ and $0.1 \mu \mathrm{g} / \mathrm{L}$ and values above $0.1 \mu \mathrm{g} / \mathrm{L}$.

ers. $^{2,3}$ The Society of Thoracic Surgeons' national database reported an average operative mortality of $2.27 \%$ for 126,107 patients who underwent elective $\mathrm{CABG}$ in $1994 .^{2} \mathrm{Tu}$ and Naylor ${ }^{11}$ reported an operative mortality of $1.9 \%$ after elective CABG in 9733 patients operated on between 1991 and 1993 in the province of Ontario. In the present study, operative mortality averaged $1 \%$ even though most patients had unstable or severe angina before the operation, 99 patients had left main coronary artery disease, and 71 had undergone previous CABG.

It appears that more sensitive end points than hospital mortality should be used to monitor the quality of care of patients undergoing elective CABG. MI and congestive heart failure after CABG are complications that reflect the overall quality of the decision and intervention process from surgical indication, coronary anatomy, grafting techniques, choice of conduits, and methods of intraoperative myocardial protection to postoperative care of patients. Although the definition and clinical significance of perioperative MI and of congestive heart failure after $\mathrm{CABG}$ remain controversial, most authors recognize that perioperative MI has a negative effect on long-term clinical results. ${ }^{13,14}$ Moreover, increase in $\mathrm{CK}-\mathrm{MB}$ after transluminal coronary angioplasty and after $\mathrm{CABG}$ is now recognized as a significant adverse event with increased late cardiac mortality. ${ }^{15,16}$

The cardiac-specific troponin $\mathbf{T}$ protein. Troponin $\mathrm{T}$ is a new and specific marker of myocardial ischemia and necrosis. ${ }^{5}$ This cardiac-specific protein is located in the thin filament of the myocardial contractile apparatus. The difference in amino acid composition between cardiac and skeletal muscle troponin $\mathrm{T}$ allows the differentiation of the two molecules by immunologic technique. Thus the serum level of troponin $\mathrm{T}$ is a useful and precise tool for diagnosis of $\mathrm{MI}^{17,18}$ and for assessment of myocardial damage during cardiac surgery. ${ }^{7,19}$ Moreover, troponin $\mathrm{T}$ has been used as an independent marker of risk in patients with acute myocardial ischemia, troponin $\mathrm{T}$ levels above $0.1 \mathrm{ng} / \mathrm{ml}$ at the time of admission being associated with a higher mortality within 30 days. $^{20,21}$

Troponin $\mathrm{T}$ is also found in a small free cytosolic amount and in a larger structurally bound fraction of myocardial cells. ${ }^{17}$ Transient leakage from the cytosolic pool through reversibly damaged cell membranes was suggested to explain the low serum levels of circulating troponin $\mathrm{T}$ in patients with unstable angina compared with patients with high serum values 3 to 5 days after MI. ${ }^{22}$

Preoperative stratification with troponin $T$. In the present study, patients with serum levels above $0.02 \mu \mathrm{g} / \mathrm{L}$ before elective CABG were older, at higher risk by clinical signs and symptoms, and had a lower left ventricular ejection fraction than patients with lower or no trace of the cardiac-specific protein. The number of cardiac events after surgery, MI and congestive heart failure, was significantly higher in the former group of patients. Nineteen percent of patients with troponin $\mathrm{T}$ serum levels higher than $0.02 \mu \mathrm{g} / \mathrm{L}$ and $23 \%$ of those with levels above $0.1 \mu \mathrm{g} / \mathrm{L}$ before $\mathrm{CABG}$ had a perioperative MI or a clinical episode of congestive heart failure after the operation (Fig. 3).

Patients with an elevated serum level of troponin $\mathrm{T}$ before the operation needed greater and longer hospital care, as shown by the difference in the use 
of vasopressor drugs, intraaortic balloon pumping, and in the period of stay in the intensive care unit and in the hospital. Postoperative troponin $\mathrm{T}$ and CK-MB serum levels were also higher among patients with detected circulating cardiac-specific troponin $\mathrm{T}$ in the preoperative period, although the difference for CK-MB levels did not reach statistical significance.

The presence of circulating troponin $\mathrm{T}$ before CABG suggests that myocardial microscopic necrosis or reversible damage to myocardial cells was present despite optimal medical treatment, normal electrocardiographic findings, and normal serum CK-MB levels before the operation. Unrecognized myocardial microscopic necrosis or reversible cell injury may be responsible for the presence of circulating troponin in patients with unstable angina and in symptom-free patients. ${ }^{21}$ Detection of a significant level of circulating troponin $\mathrm{T}$ before surgery increased the risk of perioperative MI by 2.9, and the risk of congestive heart failure after CABG by 4.8, compared with the risks in patients with little or no trace of the cardiac-specific protein. Thus high troponin $\mathrm{T}$ level before $\mathrm{CABG}$ identifies a subgroup of patients at much higher risk of serious adverse cardiac events after surgery, who require more intense and longer care than patients without detectable cardiac-specific protein.

A greater proportion of group 1 patients were subjected to warm blood cardioplegia, a method associated with lower postoperative release of serum troponin $\mathrm{T}$ than cold blood cardioplegia. ${ }^{7}$ Yet the enzyme release after the operation was significantly higher in the latter group than in group 2 patients (see Fig. 1). This also suggests that better methods of myocardial protection during CABG remain to be developed.

The present study encompasses several limitations. First, we combine the results of two clinical trials performed between 1992 and 1995; second, the threshold value for troponin $\mathrm{T}$ levels is lower than the levels chosen by other authors. ${ }^{6}$ The latter limitations could have induced misclassification of some patients in the two groups and the former explains the longer hospital stay observed in this study compared with our current practice. Although we excluded all patients with recent $(<1$ week) acute MI, high levels of troponin $\mathrm{T}$ before CABG could have been related to preoperative acute $\mathrm{MI}$ in some patients. Because there was no difference in preoperative troponin $\mathrm{T}$ levels between patients with or without recent acute MI ( $<4$ weeks from
CABG), we are confident that preoperative troponin $T$ levels were not associated with recent acute MI before CABG.

Clinical implications. Risk stratification before cardiac surgery is currently performed by means of sophisticated statistical models based on several clinical signs, symptoms, and laboratory data in large databases. This approach is of great value but depends on the quality of definition and of collection of the data. Moreover, these models present significant error and are not suitable for clinical use at the bedside in a patient population with an expected mortality rate close to $1 \%$. Preoperative troponin $\mathrm{T}$ serum level appears to identify a subgroup of patients with unrecognized myocardial necrosis or reversible myocardial cell injury, who are at a greater risk of cardiac events after the operation and who could benefit from improved methods of anesthesia, myocardial protection, surgical revascularization, and preoperative stabilization with medical treatment.

\section{REFERENCES}

1. Parsonnet V, Dean D, Bernstein AD. A method of uniform stratification of risk for evaluating the results of surgery in acquired adult heart disease. Circulation 1989;79(Suppl):I3112.

2. Edwards FH, Clark RE, Schwartz M. Coronary artery bypass grafting: The Society of Thoracic Surgeons national database experience. Ann Thorac Surg 1994;57:12-9.

3. Tu JV, Jaglal SB, Naylor CD. Multicenter validation of a risk index for mortality, intensive care unit stay, and overall hospital length of stay after cardiac surgery. Circulation 1995;91:677-84

4. Christakis GT, Ivanov J, Weisel RD, Birnbaum PL, David TE, Salerno TA. The changing pattern of coronary artery bypass surgery. Circulation 1989;80:1151-161.

5. Katus HA, Looser S, Hallermayer K, et al. Development and in vitro characterization of a new immunoassay of cardiac troponin T. Clin Chem 1992;383:386-93.

6. Ohman EM, Armstrong PW, Christenson RH, et al. Cardiac troponin $\mathrm{T}$ levels for risk stratification in acute myocardial ischemia. N Engl J Med 1996;335:1333-41.

7. Pelletier LC, Carrier M, Leclerc Y, Cartier R, Wesolowska E, Solymoss BC. Intermittent antegrade warm versus cold blood cardioplegia: a prospective, randomized study. Ann Thorac Surg 1994;58:41-9.

8. Carrier M, Pelletier LC, Searle N, Martineau R. Does retrograde administration of blood cardioplegia improve myocardial protection during first operation for coronary artery bypass grafting? Ann Thorac Surg 1997;64:1256-62.

9. Guiteras Val P, Pelletier C, Galinanes Hernandez M, et al. Diagnostic criteria and prognosis of perioperative myocardial infarction following coronary bypass. J Thorac Cardiovasc Surg 1983:86:878-86.

10. Wu AHB, Valdes R Jr, Apples FS, Gornet T, Stone MA, 


\section{Carrier et al.}

The Journal of Thoracic and

Cardiovascular Surgery

June 1998

Mayfield-Strokes S. Cardiac troponin T immunoassay for diagnosis of acute myocardial infarction. Clin Chem 1994;40: 900-7.

11. Tu JV, Naylor CD. Coronary artery bypass mortality rates in Ontario. A Canadian approach to quality assurance in cardiac surgery. Circulation 1996;94:2429-33.

12. Hodakowski GT, Craver JM, Jones EL, King SB, Guyton RA. Clinical significance of perioperative Q-wave myocardial infarction: The Emory Angioplasty Versus Surgery Trial. J Thorac Cardiovasc Surg 1996;112:1447-54.

13. Chaitman BR, Alderman EL, Sheffield LT, et al. Use of survival analysis to determine the clinical significance of new Q waves after coronary bypass surgery. Circulation 1983;67: 302-9.

14. Foree T, Hibberd P, Weeks G, et al. Perioperative myocardial infarction after coronary artery bypass surgery: clinical significance and approach to risk stratification. Circulation 1990;82:903-12.

15. Abdelmeguid AE, Topol EJ. The myth of the myocardial infarctlet during percutaneous coronary revascularization procedures. Circulation 1996;94:3369-75.

16. Kong TQ, Davidson CJ, Meyers SN, Tauke JT, Parker MA, Bonow RO. Prognostic implication of creatinine kinase ele- vation following elective coronary artery interventions. JAMA 1997;277:461-6.

17. Katus HA, Remppis A, Scheffold T, Diederich KW, Kuebler $\mathrm{W}$. Intracellular compartmentation of cardiac troponin $\mathrm{T}$ and its release kinetics in patients with reperfused and non reperfused myocardial infarction. Am J Cardiol 1991;67: 1360-7.

18. Katus HA, Remppis A, Neumann FJ, et al. Diagnostic efficiency of troponin T measurements in acute myocardial infarction. Circulation 1991;83;902-12.

19. Katus HA, Schoeppenthau M, Tanzeem A, et al. Noninvasive assessment of perioperative myocardial cell damage by circulating cardiac troponin T. Br Heart J 1991;65:259-64.

20. Ohman EM, Armstrong PW, Christenson RH, et al. Cardiac troponin $\mathrm{T}$ levels for risk stratification in acute myocardial ischemia. N Engl J Med 1996;335:1333-41.

21. Hamm CW, Ravkilde J, Gerhardt W, et al. The prognostic value of serum troponin $\mathrm{T}$ in unstable angina. $\mathrm{N}$ Engl $\mathrm{J}$ Med 1992;327:146-50

22. Lindahl B, Venge $\mathrm{P}$, Wallentin L. Troponin $\mathrm{T}$ identifies patients with unstable coronary artery disease who benefit from long-term antithrombotic protection. J Am Coll Cardiol 1997;29:43-8. 